\title{
A Review on success of community college
}

\author{
Preeti ${ }^{1}$, Mishra Sunita ${ }^{2}$ \\ Student ${ }^{1} \&$ Dean \& Head \\ Department of Human Development\& Family Studies School for home sciences Babasaheb Ambedkar \\ University (A Central University) Lucknow
}

\begin{abstract}
Many of the democratizing opportunities provided by community colleges are diminished in the eyes of policy makers by inadequate rates of success. In particular, large proportions of students who enter community colleges do not persist for longer than a semester, complete a program, or attain a credential. This review critically examines academic and policy research in search of explanations, emphasizing what is known about challenges stemming from three levels of influence: the macro-level opportunity structure; institutional practices; and the social, economic, and academic attributes students bring to college. It provides examples of how factors operating at each level affect rates of success at key times, including the initial transition to college, the experience of remedial education, and persistence through credit-bearing coursework. Its also discusses potential and ongoing reforms that could increase rates of community college success by addressing one or more areas of influence.
\end{abstract}

Key words: community college, success, students, educational, opportunity, policy.

Community colleges are a significant part of our country's educational landscape. Even though these institutions have been in existence since 1901, the 1947 Truman Commission Report gave rise to the community colleges of today. The report called for the widespread establishment of affordable public colleges that would serve community needs and offer comprehensive educational programs.1 Since then, community colleges have grown exponentially and now serve as a gateway to opportunity for millions of students. Because of their openadmissions policies, convenient locations and course schedules, close relationships with local business and industry, and lower cost relative to other institutions, community colleges are accessible to millions of students. According to the U.S. Department of Education, nearly 43 percent of all undergraduates are enrolled in a community college. 2 Given their distinct and sometimes contradictory missions and vast array of constituencies served, it is difficult to categorize community colleges and the approaches used to improve students' educational outcomes under the one-size-fit-all designation. Increased attention is being paid to the services, functions, and outcomes of community colleges, particularly as they affect student persistence and completion. A study conducted by the U.S. Department of Education found that among students who enroll in community colleges with the intent to earn a credential/degree or to transfer to a four-year institution, almost one-half do not reach this goal within six years.3 Low-income and minority students are particularly vulnerable to dropping out.4 And, while enrolled, many students require two or more remedial classes (primarily in English or math), experience difficulty covering college costs, and struggle to balance competing priorities (school, family, work). 5 All of these factors increase the likelihood of dropping out and reinforce the perception of community colleges as revolving doors. 6 Yet despite this perception - legitimate or not - community colleges remain central to conversations swirling within the higher education and policy communities around "student success." In order for such conversations to be productive and fruitful, they must begin and end with the student as the focus. Placing students at the center of institutional policy and practice can lead the way to improved student outcomes and a more equitable distribution of opportunity. One strategy for increasing student persistence and achievement outcomes lies in the area of student support services. These types of services are a standard feature at most higher education institutions. A modest body of research suggests that student support services play a role in promoting successful outcomes for community college students. When students arrive to enroll in community college, almost all are asked to take a skills assessment in math, reading, and writing. Based on these assessments, students are either categorized as "college-ready" and can enroll in college-level classes in the relevant subjects, or they are considered "developmental" or "remedial" students and are referred to academic services designed to raise their skills up to college standards. Many students are referred to multiple levels of remediation - up to five levels in some cases. This means that such students would have to successfully navigate five semesters of precollege instruction before being prepared for their first college-level course. While a variety of other remedial services are offered, the large majority consists of these semester-long developmental classes in the subjects to which students have been referred. About 60 percent of incoming students are referred to at least one developmental course.1 This is often surprising to them since the large majority of community college entrants are high school graduates. And for many, remediation is not just a course, but rather, for those 
referred to multiple levels, a whole curriculum. Addressing the needs of developmental students is perhaps the most difficult and most important problem facing community colleges. Developmental students face tremendous barriers. Less than one quarter of community college students who enroll in developmental education complete a degree or certificate within eight years of enrollment in college. In comparison, almost 40 percent of community college students who do not enroll in any developmental education course complete a degree or certificate in the same time period.2 It will be very difficult to meet the Obama administration's goal of increasing the number of community college graduates by 5 million by 2020 without making significant progress on improving outcomes for students who arrive at community colleges with weak academic skills.

\section{Mission Statement of the Student Success Learning Communities:}

As members of the California statewide Umoja Consortium, College of Alameda's Student Success Learning Communities serve as a community and significant resource designed to enhance the educational experience of African-American, Asian/Pacific Islander, and Latino students. The Student Success Learning Communities serve to

- deliberately recognize the history, contributions, and challenges of these cultural groups;

- intentionally provide a foundation for academic success by encouraging self-efficacy and personal voices;

- actively promote curriculum and pedagogy responsive to the legacy of these three communities; and

- broadly include collaborations among all three learning communities to recognize commonalities and uniqueness among groups and promote awareness of others.

\section{Institutional Need:}

Students enter the Student Success Learning Communities with a variety of personal experiences and educational obstacles, including cultural expectations and family responsibilities, a broad rage of reading and writing abilities, and varying levels of life experiences. In order to serve students effectively, the following philosophy has been adopted:

- Opportunity: Historically not all students thrive in a traditional educational setting. The Student Success Learning Communities is a student-driven program that addresses the academic needs, personal growth, and college preparedness of students.

- Awareness: Faculty meet them at their current level of preparation by validating the students' life experiences through culturally-sensitive reading materials that often reflect their own life experiences.

- Empowerment: Students are empowered to achieve independence, increased self-confidence, and an integrated understanding of themselves within the context of the academic environment, leading to full participation in the college and in the community.

\section{Organizing Principles:}

The Student Success Learning Communities

- Share a name with a core set of pedagogies and promising practices;

- Support the academic success of all students;

- Support the persistence and retention of all students toward defined educational goals: transfer, certificate, associate degree;

- Integrate both instructional and student services;

- Integrate direct instruction of information and technology literacy;

- Include recruitment and regular training of students, staff, and faculty through seminars, conferences, and other professional development;

- Facilitate the sharing of resources: financial, curriculum, methodologies, pedagogies, materials, and contacts;

- Commit to collaborating with campuses at a local level so that there is integration of the core Umoja community with the particular college mission, goals, strategic plan, and student equity efforts. [Umoja Executive Summary, September 2007, Dr. Donna Colondres and Tom Dewitt; www.umojacommunity.org].

\section{Goals:}

- Increase access

- Increase retention and persistence

- Increase enrollment

- Increase success in basic skills courses and advancement to college level courses

- Case management 
- Provide students with college orientation, educational orientation, educational and major options and career planning

- Sustain resiliency (bounce back ability)

- Enhance self-efficacy

- Build strong community by introducing students to role models and mentors

- Increase degree and certificate completion

Methodology:

- Mentorship/Tutoring

- Providing a cultural space

- Culturally specific counseling

- Workshops

- Career development and awareness

- Using technology and media for student outreach

- Navigate the system without compromising cultural identity

- Cohort/support peer to peer

- Develop learning tool for educational success (community proficiency)

- Cross cultural and racial community building through programs and social activities

- Culturally specific curriculum

- Recruiting and outreach (in reach) and outreach)

- Group counseling

- Develop academic skills

- Increase GPA

- Increase transfer rate

- Increase degree and certificate completion

- Increase grade outcome per semester

- Learn now to navigate college semester

Program Learning Outcomes

\begin{tabular}{|c|c|c|}
\hline Community Outcomes & $\begin{array}{l}\text { Community Objectives } \\
\text { (specific measures) }\end{array}$ & Assessment Methods \\
\hline $\begin{array}{l}\text { Demonstrate personal, civic, } \\
\text { social and environmental } \\
\text { responsibility an order to } \\
\text { cooperation in and } \\
\text { become a productive local } \\
\text { and global citizen. }\end{array}$ & $\begin{array}{l}\text { *Participate in Service Learning Projects } \\
\text { *Ability to plan and implement program activities } \\
\text { *Ability to correlate academic goals and skills } \\
\text { with social justice strategies } \\
\square \square \text { Awareness and interest in contemporary local } \\
\text { and global cultures and concerns }\end{array}$ & $\begin{array}{l}\square \text { Completion of assigned } \\
\text { duties } \\
\square \text { Journaling } \\
\text { - In class presentations } \\
\text { - Involvement in cross } \\
\text { campus organization } \\
\text { Global and intercultural } \\
\text { reading }\end{array}$ \\
\hline $\begin{array}{l}\text { Apply critical thinking skills } \\
\text { to be able to competently } \\
\text { process information in their } \\
\text { multiple roles: personal and } \\
\text { professional and socially. }\end{array}$ & $\begin{array}{l}\text { *Recognize the authorial agenda in literature, } \\
\text { media, and instruction } \\
\text { *Critically analyze the effect art, literature, media, } \\
\text { and legislation has on the identities and social } \\
\text { perception of working class and immigrant } \\
\text { communities of color. } \\
\text { *Strategize ways for students to ensure that their } \\
\text { sociopolitical needs are met in academic, career, } \\
\text { medical, governmental, and political institutions. } \\
\text { *Develop corporate-class written and verbal } \\
\text { communication skills } \\
\text { *Recognize the difference between speaking to be } \\
\text { heard vs. speaking to speak. }\end{array}$ & $\begin{array}{l}\text { - Creative and } \\
\text { Interdisciplinary responses } \\
\text { to in class reading } \\
\text { Group } \\
\text { projects/discussions that } \\
\text { analyze assigned literature } \\
\text { from various perspectives } \\
\text { Theatrical analysis of } \\
\text { reading } \\
\text { Critical analysis of } \\
\text { literature for } \\
\text { sociopolitical/cultural } \\
\text { awareness } \\
\text { Code switching writing } \\
\text { exercises }\end{array}$ \\
\hline $\begin{array}{lr}\text { Develop } & \text { community } \\
\text { leadership } & \text { including } \\
\text { organizing }, & \text { negotiating, } \\
\text { collaborating, cooperating }\end{array}$ & $\begin{array}{l}\text { *Develop leadership and personal accountability } \\
\text { strategies and awareness } \\
\text { *Ability to recognize, confront, and resolve } \\
\text { conflict } \\
\text { *Develop concrete strategies to use education and } \\
\text { other privileges to intercept and prevent the } \\
\text { injustices that plague poor, working class, and } \\
\text { immigrant communities of color }\end{array}$ & $\begin{array}{l}\text { - } \text { Group projects and } \\
\text { presentations } \\
\text { Student led } \\
\text { discussions/activities } \\
\text { - Service Learning } \\
\text { Assignments } \\
\text { - Whole community town } \\
\text { hall meetings } \\
\text { - Student organized } \\
\text { intercommunity festivities } \\
\text { and projects }\end{array}$ \\
\hline
\end{tabular}




\section{Conclusion :}

This paper asks whether it is possible to come up with meaningful measures of the effectiveness of community colleges. With a nod to the diverse missions of community colleges, we define two measures: one based on obtaining proficiency in an applied field of study and one based on earning transferable credits. We find that the proportion of students who succeed according to either or both of these measures (within four years of first enrolling) varies widely across community colleges. To account for differences across institutions in the preparation, aptitude, and resources of their students, we statistically correct for differences in several studentlevel predictors of success. The unexplained residuals, comparable to institutional fixed effects, yield measures of institutional effectiveness corrected for differences across colleges in the academic readiness of students. We call these measures adjusted college effects. Although these measures also show a great deal of variation, they are measured fairly imprecisely, implying that we cannot statistically distinguish among most campuses in the state.

\section{References:}

[1]. Attewell, P., Lavin, D., Domina, T., \& Levey, T. (2006). New evidence on college remediation. Journal of Higher Education, 77(5), 886-924.

[2]. Bailey, T. (2009). Challenge and opportunity: Rethinking the role and function of developmental education in community college. New Directions for Community Colleges, 145, 11-30.

[3]. Bettinger, E. P., \& Long, B. T. (2009). Addressing the needs of underprepared students in higher education: Does college remediation work? Journal of Human Resources, 44(3), 736-771

[4]. Bailey, T., Jeong, D.W., \& Cho, S-.W. (2010), Referral, enrollment, and completion in developmental education sequences in community colleges. Economics of Education Review, 29(2), 255-270.

[5]. Bean, J. P. (1980). Dropouts and Turnover: The Synthesis and Test of a Causal Model of Student Attrition. Journal of Research in Higher Education 12: 155-187.

[6]. Brint, S., and Karabel, J. (1991). The Diverted Dream: Community Colleges and the Promise of Educational Opportunity in America, 1900-1985, Oxford University Press, New York.

[7]. Chan,S.,Green,D.,(2010).Student success learning communities program review narrative report.

[8]. Community College Research Center. (2007). Do Student Success Courses Actually Help Community College Students Succeed? New York, NY: Author.

[9]. Community College Research Center. (2006). What Community College Management Practices Are Effective in Promoting Student Success? A Study of High- and Low-Impact Institutions. New York, NY: Author.

[10]. Community College Survey of Student Engagement. (2008). High Expectations and High Support. Austin, TX: The University of Texas at Austin, Community College Leadership Program.

[11]. Griffith, M., and Connor, A. (1994). Democracy's Open Door: The Community College in America's Futunity re. Portsmouth, NH: Boynton/Cook Publishers, Inc., p.20.

[12]. Goldrick-Rab,S.,(2010).Challenges and opportunities for improving community college student success.Review of educational research $80(3)$ 437-469.

[13]. Heavy Runner, I. and De Celles, R. (2002). Family Education Model: Meeting the Student Retention Challenge. Journal of the American Indian, 41(2).

[14]. Dougherty, K. J., and Townsend, B. K. (2006). Community college missions: A theoretical and historical perspective. New Directions for Community Colleges: 5-13.

[15]. Ladd, H. F., and Loeb, S. (in press). The challenges of measuring school quality: Implications for educational equity. In D. Allen and R. Reich (Eds.), Education, democracy and justice. University of Chicago Press, Chicago.

[16]. North Carolina Community College System, 2009 Critical Success Factors (Raleigh: NCCCS, June 2009).

[17]. North Carolina Community College System. 2008-2009 Annual Statistical Reports (Raleigh, NCCCS, May 2009).

[18]. Oreopoulos, P., and Salvanes, K. G. (2011). Priceless: The Nonpecuniary Benefits of Schooling. Journal of Economic Perspectives 25: 159-184.

[19]. Tinto, V. (1975). Dropout from Higher Education: A Theoretical Synthesis of Recent Research. Review of Educational Research 45: 89-125.

[20]. University of North Carolina General Administration. (2009). 2008-2009 Statistical Abstract of Higher Education in North Carolina (Chapel Hill, UNC-GA)

[21]. U.S. White House. (2009). Investing in Education: The American Graduation Initiative, July 14, 2009. http://www.whitehouse.gov/blog/Investing-in-Education-The-American-Graduation-Initiative/, 10/21/10. 21 